\title{
SfM photogrammetry for GeoArchaeology
}

Sara Cucchiaro ${ }^{*}$, Daniel J. Fallu', Pengzhi Zhao ${ }^{3}$, Clive Waddington ${ }^{4}$, David Cockcroft ${ }^{4}$, Paolo Tarolli ${ }^{1}$, Antony G. Brown ${ }^{2,5}$

${ }^{I}$ Department of Land, Environment, Agriculture and Forestry, University of Padova, Agripolis, viale dell'Università 16, 35020 Legnaro (PD), Italy

${ }^{2}$ Tromso University Museum, UiT The Artic University of Norway, Kvaløyen 30, Tromsø, Norway

${ }^{3}$ Earth \& Life Institute, Université Catholique de Louvain, Louvain-la-Neuve, Belgium

${ }^{4}$ Archaeological Research Services Ltd, Angel House, Portland Square, Bakewell, DE45 1HB, UK

${ }^{5}$ Geography and Environmental Science, University of Southampton, UK

\section{Submitted to the Book Remote Sensing of Geomorphology (Elsevier book series Developments in Earth Surface Processes)}




\section{Abstract}

1 Geoarchaeological studies have benefits from new technological developments in remote sensing

2 technologies that have become an integral and important part of the archaeological researches. In

3 particular, Structure from Motion (SfM) photogrammetry is one of the most successful emerging

4 techniques in high-resolution topography (HRT) and provides exceptionally fast, low-cost and easy

5 3D survey for geoscience applications. In this chapter we present an example of SfM application for

6 geoarchaeology. The purpose is to realize HRT DTMs (Digital Terrain Models) of an area of

7 prehistoric agricultural terracing together with a geoarchaeological excavation trench in the Ingram

8 Valley, Northumberland National Park, NE England. The study area is one of the six pilot case studies

9 of TerrACE archaeological research project (ERC-2017-ADG: 787790, 2018-2023;

10 https://www.terrace.no/), a five-year European Research Council grant funded by European Union.

11 An integrated approach utilising ground-based and UAV (nadir and oblique) images was used to

12 preserve fine-grained topographic detail and permit the accurate survey of highly vegetated areas and

13 steep or sub-vertical surfaces (e.g., vertical walls of terraces), while also allowing for the capture of

14 large spatial data sets. The SfM-DTM provided an accurate and high level of detail of the terrace

15 landscape, the archaeological features and the soil and sediment stratigraphy along the excavation

16 trench. An additional terrace was identified that had not been recognised before due to the HRT study

17 bringing out a level of detail that had not been previously observable in this area. The SfM 3D outputs

18 allowed the extraction of profiles, sections, scaled plans and orthomosaics of the terrace complex and

19 the excavation trench, simplifying and speeding the archaeologist's field and laboratory work. SfM

20 has shown it to be a rapid, cost-effective and highly accurate technique for surveying archaeological

21 sites at both a landscape and localised scale and adding new and more accurate information in

22 nationally important landscapes and beyond. 
24 Keywords: Structure from Motion (SfM), Digital Terrain Models (DTM), Unmanned Aerial

\section{Remote Sensing}

The use of Remote Sensing (RS) data, from imaging to scanning has now become an integral and routine part of geoarchaeological studies. Even in the early days of aerial photographic imagery it was realized that this technology could, under different light and ground conditions, reveal significant sub-surface information, particularly in arable lands through so-called 'crop-marks' (Barber 2011). In addition, site recording (or planning) was routinely augmented by high-resolution oblique photography from extendable poles or photographic towers (Fussell 1982). This offered some 3D capability from stereo pairs, but this was limited and digital photogrammetry has only really advanced with the advent of DSLR cameras, sufficient computing power (Doyon et al., 2019).

The next major RS development in geoarchaeological studies was the use of wavelengths at the edge or outside the visible part of the electromagnetic spectrum, particularly near infra-red (NI) and infrared (IR). NI has proved particularly valuable for demarcating field systems, including infields from outfields, and settlement plans through differences in vegetation and soil properties (Verhoeven et al. 2009; Verhoeven 2012). Examples include Bronze Age fields systems on Bodmin Moor, UK (Johnson et al., 2008), and the mapping of the Roman town of Altinum on the Po Plain during a severe drought in 2007 (Ninfo et al., 2009). Although it was realized that satellite remote sensing could be valuable for archaeology back in the early days of its availability (Lasaponara and Masini 2011), the low spatial resolution of early data limited its use in geoarchaeology to large-scale systems, such as irrigation networks and tells in semi-arid regions (Kouchoukos 2001; Parcak 2007). However, from the availability of data from the Landsat TM satellite (which had a spatial precision of $30 \mathrm{~m}$ ), and SPOT satellite (with resolution down to $10 \mathrm{~m}$ ) onwards, more geoarchaeological applications have 
emerged. Examples include the mapping of Roman centuriation (Romano and Tolba 1996) and the landscape around Stonehenge in England (Fowler 1995). Even higher spatial resolution with Quickbird satellite multispectral imagery has allowed the use of both NIR and more complex indices such as the Normalised Difference Vegetation Index (NDVI) for the mapping of medieval crop marks in southern Italy (Lasaponara and Masini 2007). The advantage of NDVI is it can detect crop marks through the vigour of crops or other vegetation. A related method is the Tasselled cap transformation which can be used to estimate soil depth in ploughed fields (Brown et al., 1990).

The advent in the 1990s of airborne scanners was a revolution in the use of RS data in geoarchaeology. Active methods, such as Light Detection and Ranging (LiDAR), have now become almost a standard in archaeology (Beach et al., 2019; Brown 2008; Evans et al., 2013; Hämmerle and Höfle 2018; Penny et al., 2019; Tarolli et al., 2019) and can provide invaluable information in three ways; firstly because of the ability of LiDAR to penetrate vegetation including woodland, secondly because of the reflection of sub-surface conditions through micro-topography, and thirdly because of the potential information value of additional data, such as intensity of the return signal. One of the first demonstrations of the ability of LiDAR to penetrate woodland was the discovery of field boundaries under ancient woodland in the Forest of Dean, UK (Hoyle 2008), which was quickly followed by other National Parks in the UK and elsewhere including the USA (New Forest 2016; South Downs National Park 2019; USGS 2011). Combining LiDAR data with that from aerial photographs and geomorphological mapping to drive geoarchaeological evaluation and prospection programmes in advance of development, particularly for large quarries, was pioneered in northern England as part of the Till-Tweed project (Passmore and Waddington 2009; 2012) and which gave rise to the endorsement of this approach in English planning guidance (MHEF 2008). LiDAR has been used in the archaeological evaluation of large developments such as the high-speed rail projects (Georges-Leroy et al., 2013). High-resolution topography can both reflect human activities (such as cultivation ridges; Tarolli et al., 2014) and/or natural features such as paleochannels that are sediment traps ideal for geoarchaeological studies. Indeed, this has been formalized into a protocol for the 
evaluation of the geoarchaeological potential of areas of gravel extraction that commonly border floodplains in Europe (Carey et al., 2006; 2017). In these studies, the intensity of LiDAR return is used to map wetter areas which normally correspond to deeper soils, fine and organic sediments and negative features. The most advanced scanning currently is the use of airborne multi and hyperspectral scanners which again can be used for crop marks (Aqdus et al., 2008), classical city plans (Cavalli et al., 2007) and even shallow marine features and survey (Guyot et al., 2019).

In many ways the development of ground-based systems has mirrored that of airborne remote sensing, except that developments in civil engineering and geological monitoring were also important. Early long-range distance laser scanners were used in the early 2000s to monitor cliff failures (Lim et al., 2010; Rosser et al., 2005), river bed morphology (Brasington et al., 2012), debris flow (Blasone et al., 2014), rockfalls (Williams et al., 2018), and glacial environments (Whitworth et al., 2006). The earliest and invaluable archaeological applications of terrestrial laser scanners (TLS) was in cave mapping which allowed the modelling of cave geometry and the creation of exact replica caves (González-Aguilera et al., 2009), and the recording of complex ancient Classical world structures (Brutto et al., 2017). TLS has unrivalled utility in the scanning of inaccessible archaeology, such as inter-tidal archaeology and it can be used to model processes associated with archaeological features such as tidal mill basin volume (Lobb et al., n.d.). Due to both its accuracy and speed, TLS is also highly suited to the monitoring of erosion that can threaten archaeological sites such as coastal prehistoric sites around the North Sea (Lobb and Brown 2016). A development - terrestrial hyperspectral scanning - has been used to record excavation stratigraphy from a Neolithic site in northern Sweden (Linderholm et al., 2019). Both high-resolution aerial photography and TLS are particularly suitable for mapping cultivation terraces and lynchets (cultivation ridges on slopes) which due to their scale (1-5m in typical riser height) are not normally recorded on topographic maps. This has been done for historic period agricultural terraces in Catalonia (Kinnaird et al., 2017) and is applied here to prehistoric terraces. Now, new high-resolution survey techniques are available and they allow us to undertake low-cost and very detailed surveys in the field of geoarchaeology. One of 
the most successful emerging techniques in high-resolution topographic (HRT) survey is SfM

101 (Structure from Motion) photogrammetry (Westoby et al., 2012), which was born from the evolution of classical photogrammetry but exploits the advantages of digital photography and computer vision.

\section{SfM photogrammetry}

Nowadays, SfM photogrammetry paired with multi-view stereo (MVS), hereafter together referred to as SfM, represents a powerful and successful tool to produce high-quality three-dimensional (3D) surfaces for geoscience applications. In literature, several researches have used this technology to carry-out different kinds of analysis and studies on: structural geology (e.g., Bemis et al., 2014); debris-flow dynamics (Cucchiaro et al., 2019); surveying submerged surfaces (e.g., Woodget et al., 2015; Dietrich 2017); soil erosion (Glendell et al., 2017); design of drainage network (Pijl et al., 2019) or agricultural terraces 3D reconstruction (Pijl et al., 2020); gullies and badlands (e.g., Stöcker et al.,

111 2015; Smith and Vericat 2015; Koci et al., 2017); fluvial morphology (e.g., Javernick et al., 2014; Marteau et al., 2017) and aquatic applications (Carrivick and Smith 2018); glaciers (e.g., Immerzeel et al., 2014; Piermattei et al., 2015; Mallalieu et al., 2017); monitoring on landslide displacement 114 (e.g., Stumpf et al., 2015; Clapuyt et al., 2017; Eker et al., 2018; Turner et al., 2015); coastal recession 115 (e.g., James and Robson 2012; Westoby et al., 2012); open-pit mining areas (Chen et al., 2015; Xiang et al., 2018); extraction of biophysical forest or plants parameters and monitoring (e.g., Iglhaut et al., 2019; Malambo et al., 2018; Zarco-Tejada et al., 2014). Moreover, studies are shifting from proofof-concepts in topographic survey to genuine applications including quantification of bathymetric surveys, underwater archaeology, grain-size mapping, restoration monitoring, habitat classification, geomorphological change detection and sediment transport path delineation (Carrivick and Smith 121 2018). In short time, SfM has had a transformative effect on geoscience research providing exceptionally fast, low-cost and easy 3D survey (Fonstad et al., 2013), with point accuracies 
the same order of magnitude as those obtained with more traditional HRT survey methods for a broad range of landforms and landscapes. SfM has proved to be extremely versatile and useful in different environments where traditional techniques had high costs. For example, in complex and rugged environment, the use of methods such as TLS is limited by access constraints (e.g., for large instruments) and the power requirements in remote areas (Westoby et al., 2012). The use of LiDAR

130 for surveys of small extension has still relatively high costs, requires specific processing and 131 sometimes does not reach the required accuracy and the point density in complex terrains (Victoriano 132 et al., 2018), whereas SfM images acquisition is several orders of magnitude cheaper. Furthermore, 133 the issues of cost and time constraints for some methods can make it difficult to conduct repeated 134 surveys, that is multi-temporal surveys needed to properly characterize geomorphic processes.

135 The increasing use of a SfM is linked to the development of user-friendly SfM software (Cucchiaro 136 et al., 2018b) and the use of the unmanned aerial vehicles (UAV) that have evolved greatly in the last 137 decade in electronic sophistication, ease-of-use and reduced cost. Now, there are different kind of 138 UAVs that meet different requirements in the SfM surveys (Carrivick et al., 2016). Moreover, SfM 139 allows the choice of a wide range of other acquisition platforms (Table 1) based on the features of 140 the surveyed area: pixel resolution, spatial coverage, image quality, and cost-effectiveness (Smith et 141 al., 2015).

Table 1: SfM platforms types and their features.

\begin{tabular}{|l|l|l|}
\hline \multicolumn{1}{|c|}{ SfM platforms } & \multicolumn{1}{|c|}{ Main features } \\
\hline Fixed-wing aircraft & $\begin{array}{l}\text { Long-range capability, highly efficient in terms of energy wise, demands } \\
\text { a take-off and landing strip (not be feasible in remote and/or rugged } \\
\text { terrain) }\end{array}$ \\
\hline Dual rotor systems (e.g., Heli) & $\begin{array}{l}\text { Restricted battery life, highly flexible systems for almost any terrain, not } \\
\text { suitable in blustery conditions }\end{array}$ \\
\hline Multicopters & $\begin{array}{l}\text { High flexibility in complex topography and stability in most weather } \\
\text { conditions, but limited range and flight time }\end{array}$ \\
\hline Kites, lighter-than-air balloons & $\begin{array}{l}\text { Full control over the frequency and target of image acquisition, not } \\
\text { suitable in windy conditions, limited by a moderate maximum operation } \\
\text { height }\end{array}$ \\
\hline Gyrocopter & Wide swath imagery, flying not possible in adverse weather \\
\hline Hand-held poles & Fine spatial resolution imagery, complete control over image acquisition scale & Detail scale \\
\hline Ground-based (Hand-held) & $\begin{array}{l}\text { Detail-scale 3D reconstruction, especially of the steep or sub-vertical } \\
\text { surfaces, limited spatial coverage }\end{array}$ \\
\hline
\end{tabular}


144 The SfM technique also offers the possibility of integrating images taken from different acquisition 145 platforms if certain working methods are respected. For example, an integrated approach combining 146 ground-based and aerial images can help overcome site-specic disadvantages (e.g., ground-based 147 images are not able to guarantee areal coverage, while aerial photos may show a poor representation 148 of vertical surfaces, being influenced by the vegetation). However, to carry out the data-fusion 149 between aerial and ground photos, it is important to use the same camera with the same focal length 150 to minimize the integration problems in the photogrammetric models (Cucchiaro et al., 2018a). This 151 approach also benefits from the acquisition of data from two different observation directions (i.e., 152 nadir for UAV images and oblique for terrestrial images; Stöcker et al., 2015). In general, the choice 153 of the sensor, the flight height and the focal length are fundamental aspects to be considered 154 (O’Connor et al., 2017).

155 The application of SfM photogrammetry technique also requires the appropriate software to post156 process photos and a Ground Control Points (GCPs) network to scale and georeference the SfM results. GCPs are fundamental for the accuracy and repeatability of the survey (James et al., 2017a; James et al., 2017b).

159 The great versatility of SfM is now offering an optimal platform for archaeology (Bojakowski et al., 160 2015; Howland et al., 2014; Mertes et al., 2014; Landeschi et al., 2016; Pierdicca et al., 2016; Prins 161 et al., 2014) that benefits from fresh technological developments to record the 3D structures. Indeed, 162 the traditional protocols based on hand-drawn plans and sections no longer come up to the standards 163 of precision achieved by the new methods in recording the archaeological structures more accurately 164 (López et al., 2016). The results of SfM photogrammetry can be processed further to create 3D models 165 and scaled plans for the study of the physical and functional characteristics of surveyed objects and, 166 in geoarchaeology research where it can record both topographies and sections. 


\section{SfM in Geoarchaeology: Agricultural Terraces in Europe}

Agricultural terraces are not just archaeological features but were fundamental to the success of European agriculture in hilly terrains, and were until recently, part of a sustainable agricultural and social system. TerrACE archaeological research project (ERC-2017-ADG: 787790, 2018-2023; https://www.terrace.no/) is a five-year European Research Council grant funded by European Union. The goals of the TerrACE Project are to create a methodological step-change in the understanding of terraces by applying new scientific methodology to agricultural terraces across Europe, by bringing together landscape archaeology, geomorphology and paleoecology. The techniques address several themes including: the mapping and recording of terraces and lynchets in as finer detail as is possible, dating terrace systems and understanding their original and later purposes and use. The improve mapping of terrace landscapes can be reached thought HRT techniques (Sofia et al., 2014), also using automatic extraction algorithms Tarolli et al. (2014). HRT can be used to identify agricultural terraced walls, spatial heterogeneity and multi-temporal measures of terrace degradation through topographic attributes. These approaches start from the availability of large-scale topographic LiDAR datasets, that allow construction of a high-resolution ( $\sim 1 \mathrm{~m})$ DTMs (Digital Terrain Models) from the bare ground data, by filtering vegetation from raw LiDAR data. These allow the mapping of terraces in areas where photointerpretation is not possible, such as through woodland, and in areas where no previous information is available; for example, vegetated terraced sites in remote zones. The LiDAR data can be used for a first and rapid assessment of the location of terraces particularly in abandoned systems that might require management and renovation planning. Moreover, the proposed procedure is an efficient approach that overcomes classic difficulties associated with working on large scales, approaching private owners and accessing terraced areas for conducting ground surveys over large areas. Once terraced sites have been labelled and identified, the SfM technique (using UAV) can be used to carry out higher resolution surveys and DTMs ( $\sim 0.25 \mathrm{~m}$ to $0.10 \mathrm{~m})$ useful to analyse in detail the topographic features (scaled plans, profiles and sections) and attributes of terraces systems. 
Instead, in the areas where the LiDAR data are not available or sufficiently accurate in terms of

193 resolution, the SfM technique offers the possibility, as mentioned above, to carry out very detailed 194 surveys to detect terraced areas trough a specific workflow in which multiple acquisition platforms 195 can be used to overcome the limits related to the SfM survey scale and vegetated zones.

\subsection{Case study: Ingram Valley (UK)}

197 The TerrACE project is examining a sample of terrace systems that represents nearly all of Europe's 198 climatic zones in 6 study areas: Ingram Valley and other sites in the UK (maritime temperate; 199 Frodsham and Waddington 2004), Leikanger and Sognefjorden, in Norway (cool maritime; Skrede 200 2005), Pays de Herve, Belgium (continental temperate; Van Oost et al., 2000), Valla d'Arene and St. 201 Victoire in the French Alps (humid Mediterranean; Walsh and Mocci 2003), Cinque Terre Ligurian 202 Hills, and GIAHS (Globally Important Agricultural Heritage Systems) Soave Traditional Vineyards 203 in Italy (Mediterranean; Tarolli et al., 2014), Stymphalos and sites in eastern Crete (dry 204 Mediterranean; Walsh et al., 2017). The study presented here is from the first study case in the Ingram 205 Valley in the Cheviot Hills of NE England within the Northumberland National Park (Fig. 1). The 206 site is located immediately adjacent to Plantation Camp enclosure on the east slope of the hillside 207 below Brough Law Hillfort, approximately $1 \mathrm{~km}$ west of Ingram village in the upper Breamish valley. 


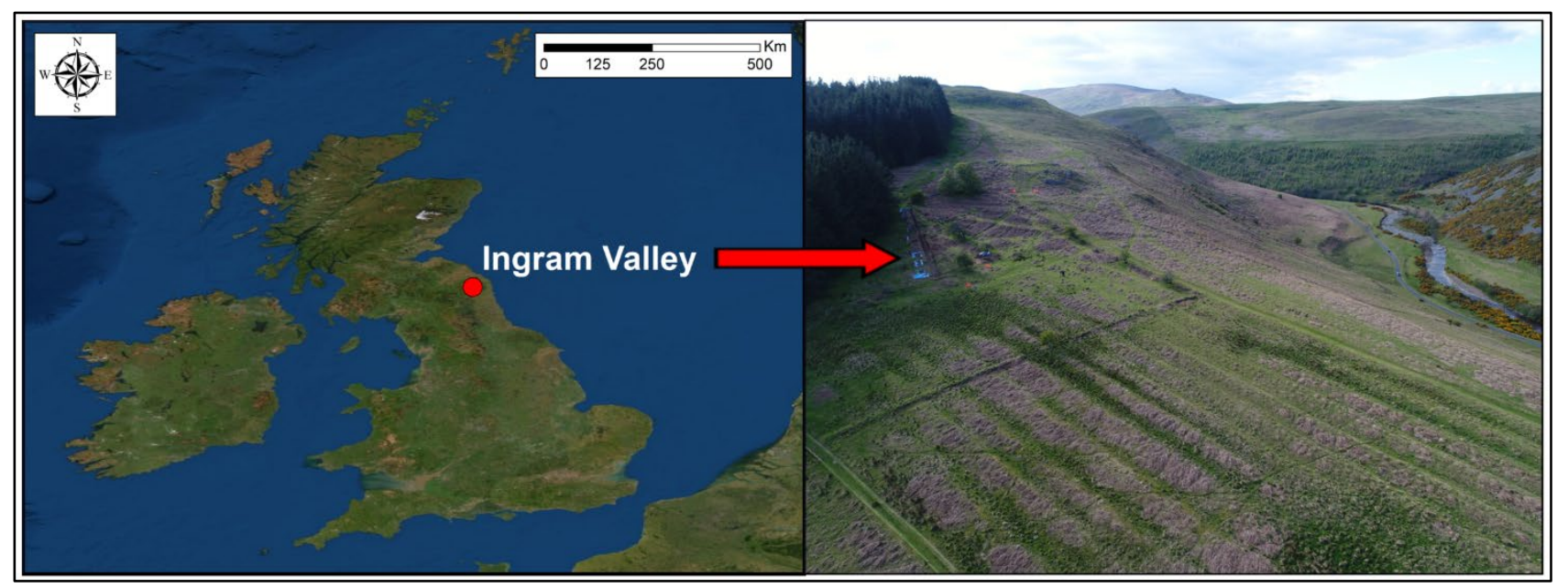

Figure 1: Location of study area. Ingram Valley - Northumberland National Park (UK). The photo (taken in May 2019) shows the Ingram Valley looking north-west with medieval ridge and furrow in the foreground, the prehistoric agricultural terraces to the right of the plantation cloaked in brown vegetation and the river Breamish further to the right.

212 The park is known for its upland multi-period archaeological landscapes (Frodsham and Waddington 2004) and the features on Ingram Farm are a Scheduled Monument because they are a fine example of this multi-layered or palimpsest landscape (Lotherington and Waddington 2019). Features include cairnfields, settlements, hillfort/enclosures, field systems and agricultural terraces. It is one of the largest Scheduled Monuments in England $\left(5.7 \mathrm{~km}^{2}\right)$. This study focusses on the Plantation Camp agricultural terraces which have received previous archaeological attention. Two trenches were excavated in 1997/8 and a longer trench in 1999 by Waddington (Frodsham and Waddington 2004).

219 The archaeological sequence comprises the cultivation terraces as the earliest component which are 220 currently radiocarbon dated as commencing in the Early Bronze Age c.1800-1500 BC, which are in 221 turn overlain by a trackway that leads to a late Iron Age or Roman Iron Age enclosure (Plantation 222 Camp). Further up the hillside on the crown of the hill is the well-preserved remains of a stone-walled 223 hillfort known as Brough Law which has been radiocarbon dated to the first few centuries BC in the 224 late Iron Age. The next phase of activity is evidenced by a large expanse of broad ridge and furrow 225 cultivation remains of Anglo-Saxon origin that overly the lowest part of the prehistoric cultivation terraces. A post-medieval stone-walled enclosure and outfield boundary system overlies the ridge and 
undertaken as part of this project is of national importance. In all there are seven terraces covering a

229 small area of about $9000 \mathrm{~m}^{2}$ (Fig. 2a). Important aims of the work include determining the form and 230 construction of the terraces which initially appeared indeterminate in form between true bench-type 231 terraces with wall risers and lynchets. The case presented here is particularly interesting and 232 challenging as in the Ingram landscape there is a palimpsest of terraces from the prehistoric to the 233 post-medieval period and very thick vegetation cover in the form of bracken. We also aim, eventually, 234 to be able to tie the subsurface and chronostratigraphic models together in $4 \mathrm{D}$ agricultural terrace 235 heritage models. Satellite imagery from Google Earth vaguely shows the prehistoric agricultural 236 terracing running along the contour, with the much later better-preserved medieval ridge and furrow 237 (Fig. 2c) showing clearly running across the slope. It is also just visible on open source LiDAR data 238 provided by the UK Environment Agency (Data Service Platform; https://environment.data.gov.uk/ 239 ). This LiDAR data covers the whole Ingram valley (Fig. 2b), however, the DTMs derived from 240 LiDAR survey have a resolution of $2 \mathrm{~m}$ ( $\underline{\text { Fig. } 2 \mathrm{~b}}$ ), which is not enough to identify and map in detail 241 all the terraces and lynchets in the study area (some of them have heights below one meter). For this 242 reason, a SfM survey was carried out to realize higher resolution topographic data of the Ingram 243 terrace area together with the excavation and sampling from a new geoarchaeological excavation 244 trench $(65 \mathrm{~m}$ by $1 \mathrm{~m})$, that encompassed the length of the prehistoric agricultural terrace sequence. 245 The HRT survey facilitated the analysis of geomorphological features, the topographic recording and 246 measurement of the various archaeological remains, as well as the recording of the excavation, based 247 on the high-resolution data from the DTM. 


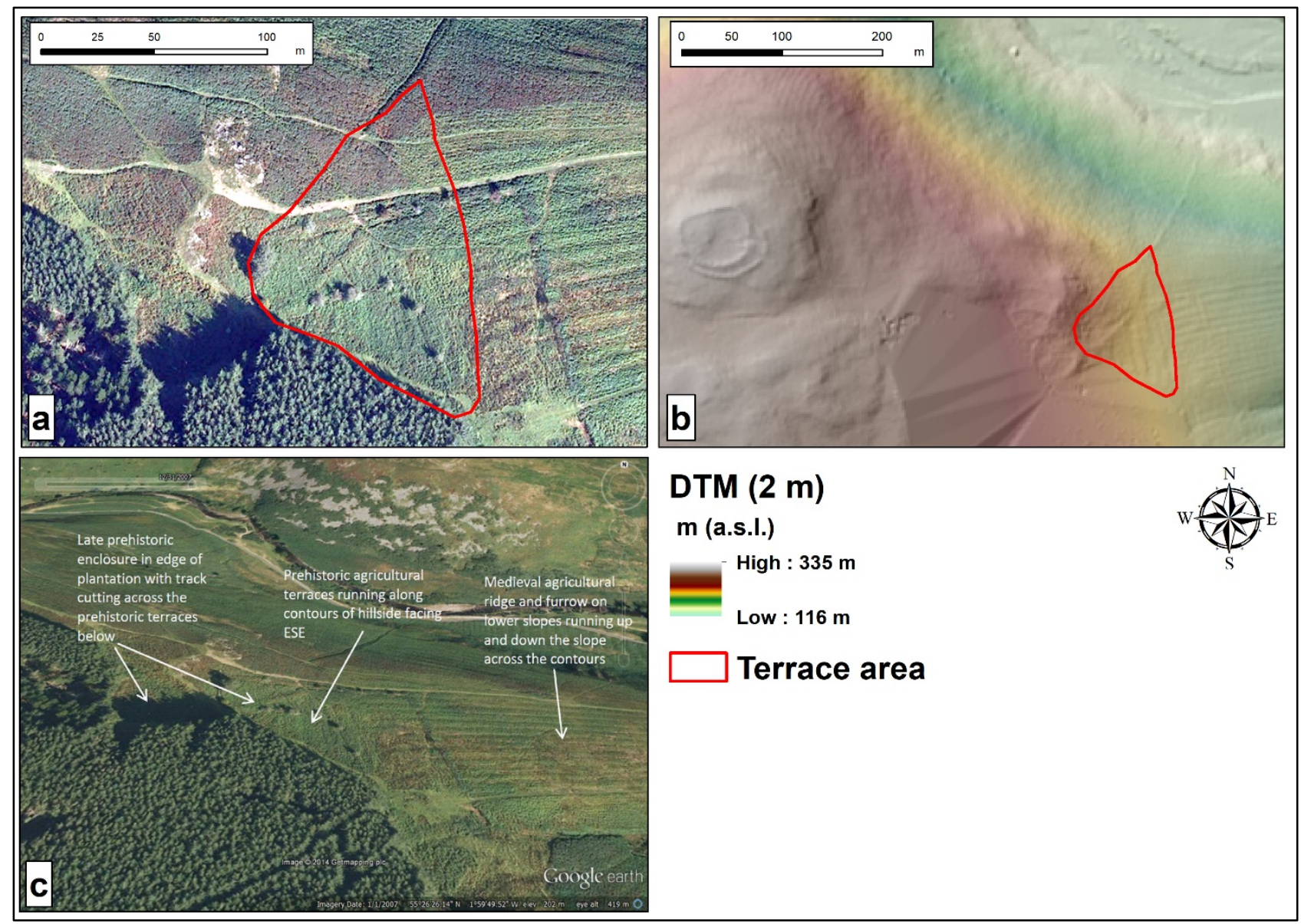

Figure 2: The Ingram terrace site: a) Orthophoto of terraces site in 2007. b) DTM of Ingram Valley at $2 \mathrm{~m}$ resolution provided by the

UK Environment Agency. c) Screenshot of satellite imagery from Google Earth of Ingram terraces site with the prehistoric agricultural terraces, Plantation Camp enclosures, and the medieval ridge and furrow marked.

\subsection{SfM workflow}

\subsubsection{Fieldwork}

In SfM surveys the choice of the appropriate SfM platform is a key aspect. After a detailed analysis

255 of the field site, we decided to integrate ground-based and UAV (nadir and oblique) images because

256 this area is very challenging to survey on the ground given the huge level of bracken infestation across

257 the lower slopes of the hillside covering the medieval ridge and furrow and the agricultural terraces

258 (Fig. 4a). The aerial survey gave us the possibility of covering a large area in a short time, and 259 therefore we chose to survey a wider zone (around 40 ha; Fig. 3) than just the terrace area, while the 260 ground-based photos captured the fine and otherwise hidden details. In particular we analysed the 
261 area from the Brough Law hillfort (situated overlooking the Plantation Camp terraces as well as the 262 much of the rest of the nearby Breamish Valley) to the Breamish river to study the long-term evolution 263 of this tract of landscape in finer detail than was hitherto possible. By surveying up to the river this 264 allowed the morphology of the valley side to be compared with that of the valley floor and the 265 opportunity to determine whether past agricultural remains could be detected on the flood plain, as 266 well as any evidence for surviving palaeo-environmental deposits in features such as infilled palaeo267 channels.

268 Since the study area was large, it encompassed considerable variation in slope morphology (Fig. 4b), 269 complex topography and vegetation cover (Fig. 4c). The study area was therefore divided into 270 different SfM zones (Fig. 3) that were surveyed through planned and manual UAV flights tougher 271 with ground-based photos in May 2019. Nadir and oblique UAV images were collected with a DJI 272 Zenmuse X4S camera (20 Mpixels, focal length $8.8 \mathrm{~mm}$, 1-inch CMOS Sensor) mounted on a 273 professional UAV (DJI Matrice210v2; Fig. 4d), that has high flexibility and stability in most weather 274 conditions and needs only a small space for take-off and landing. In zones with uniform altitude 275 (a.s.1.), the UAV flight control unit (coupled to a GNSS) was used to plan the UAV flight strips using 276 software that adjusts the height and speed of flight accordingly, and the image overlap (optimal 277 overlap is $80 \%$ in flight direction and a flight strip overlap of $60 \%$ ). The flight altitudes were in the 278 range of 25-45 $\mathrm{m}$ to ensure high resolution and a sufficiently large overlap (image footprint with a mean Ground Sampling Distance of 0.006-0.011 m). In areas with important slope change, the manual 280 flight mode was used with a time-lapse function of the camera that allowed the capture an image at 3 281 s intervals, sufficient to guarantee the overlap in sequential photographs, which is essential for the 282 image matching algorithms used in SfM (Eltner et al., 2016). Ground-based and UAV images (nadir 283 and oblique photos very close to the ground) were taken in vegetated areas (Fig. 4c), over the terrace 284 complex and along the trench excavation (Fig. 4e and f) using the same Zenmuse X4S camera to 285 maximize the resolution of the SfM survey. For the ground-based surveys, the photographs were 
287 between adjacent camera positions, to avoid large jumps in scale.

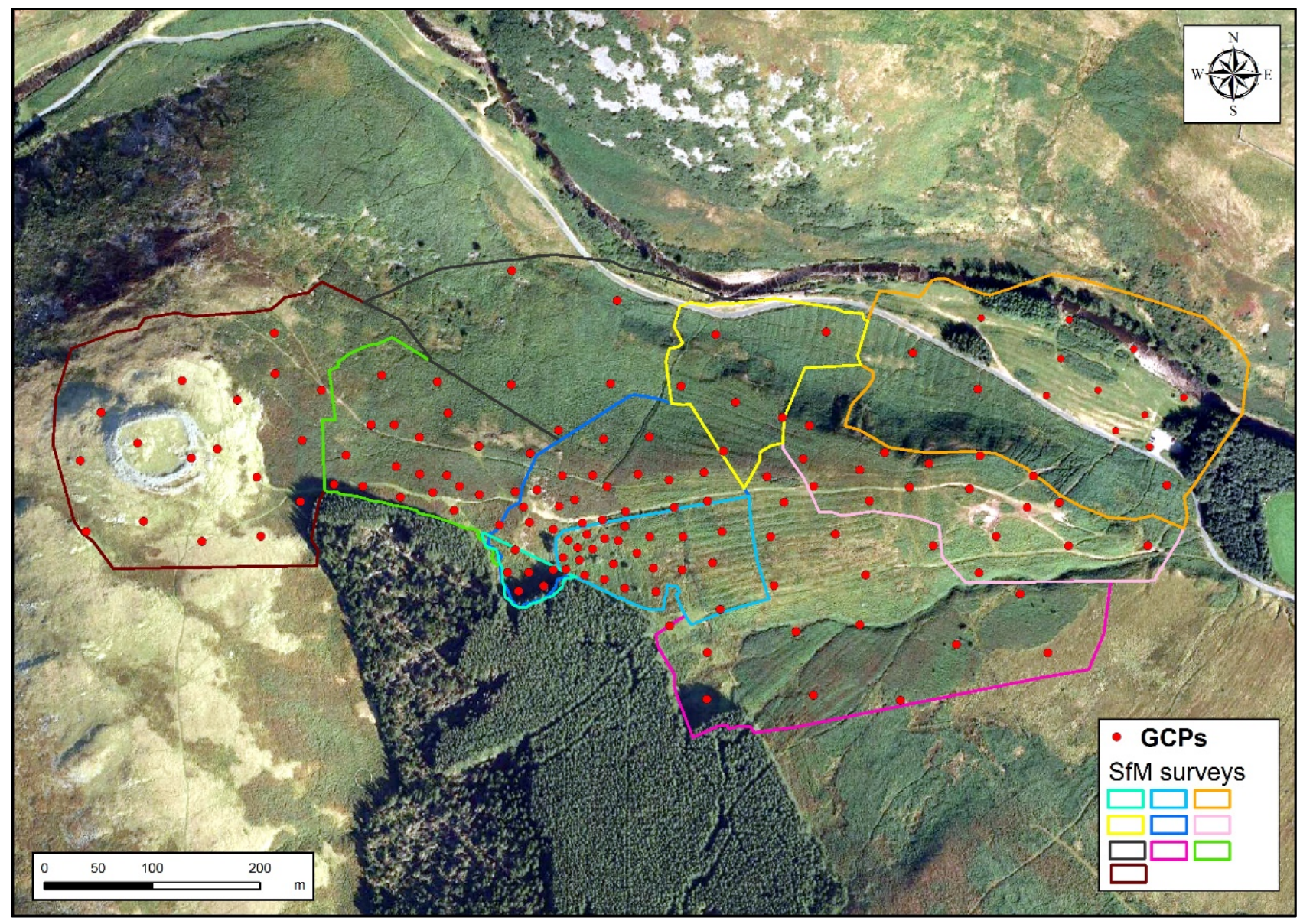

290 Before image acquisition, the GCPs (Fig. 3 and 4b) were distributed throughout the study area so

291 that GCPs could be visible in as many images as possible and easily distinguishable from the 292 surrounding landscape (Smith et al., 2015). Indeed, the number, location and distribution of GCPs is 293 a fundamental aspect and was based on the features of the studied area, extension and desired 294 resolution (Cucchiaro et al., 2018a). A Leica ATX1230 GG GNSS allowed us to survey n = 137 GCP 295 (Fig. 3) with a planimetric positional accuracy ranging from 0.02 to $0.03 \mathrm{~m}$ and vertical uncertainties 296 ranging from 0.03 to $0.04 \mathrm{~m}$ in RTK (Real-Time Kinematic) mode. All the points coordinates were 297 referred to the British National Grid (EPSG: 27700) reference system. 




299 Figure 4: Pictures from the Ingram field survey: a) The geoarchaeology excavation trench cut over the terrace complex, b) Example of GCP used in the SfM survey, c) The circular-shaped Plantation Camp enclosure now cloaked in vegetation with trees in its centre, 


\subsubsection{SfM processing}

Processing of SfM datasets is not limited by the SfM method or by the camera platform but by computing power, which with modern computers and GPU processing, for example, is becoming much less of a limitation than with early geoscience usage of SfM (Carrivick and Smith 2018). Thus, large scale processing works, like this need powerful computers and SfM photogrammetry software. The image dataset $\left(\mathrm{n}^{\circ}\right.$ of photos 3782$)$ was processed with an 2 xIntel ${ }^{\circledR}$ Xeon ${ }^{\circledR}$ Bronze 3106 CPU extract the 3D point clouds from the images, creating 3D models of the scene and, additionally, orthomosaics. The first preliminary step is masking (Fig. 5a) unwanted objects (e.g., water, vegetation and clouds in ground-based images) in the photos uploaded in the software. Then, five main steps were followed: (i) camera calibration using Agisoft Lens, an automatic lens calibration routine which uses LCD screen as a calibration target and supports estimation of the camera calibration matrix of DJI Zenmuse X4S, including non-linear distortion coefficients. This precalibration step was useful to estimate camera parameters that were used in the next process i.e., (ii) alignment where ground-based and UAV photos were directly fused to the alignment process in Photoscan to avoid subsequent data fusion problems at level of point clouds (Cucchiaro et al., 2018a). During the alignment step common features in the set of images were identified and matched, the internal camera parameters and relative orientation of the camera at the time of image acquisition were estimated, and construction of the image network took place (Carrivick et al., 2016; Piermattei et al., 2016). This first alignment ("Low accuracy" in Agisoft Photoscan) allowed the removal of unwanted (e.g., vegetation; Fig. 5b) or outliers data (i.e. points that are clearly located off the surface or have anomalous large image residuals), and deleting the photos that the software do does not align 
327 for different reasons. (iii) Scaling and georeferencing of the 3D sparse point cloud using a seven328 parameter linear similarity transformation based on XYZ coordinates of GCPs (Smith et al., 2015), 329 evaluating the level of GCPs uncertainty before to including these data to avoid adversely affecting 330 data accuracy (James et al., 2017a). The location and manual marking of GCPs (Fig. 5a) on at least 331 two photographs helped to remove deformations such as the "dome effect" (James and Robson 2014), 332 and to refine the camera calibration parameters (Fonstad et al., 2013; Eltner et al., 2016). Some of the 333 GCPs (1/3) were used as Control Points (CPs) in the different Agisoft Photoscan projects to provide 334 an independent measure of accuracy (the difference between the real coordinates in this point and the 335 modelled values; i.e., residuals). With GCPs, the alignment ("High accuracy" in Agisoft Photoscan) 336 was re-run to improve the image alignment in light of this information. (iv) Camera optimization: 337 refined the camera and tie-point locations (homologous points that link different images), and the 338 camera calibration parameters of each image, through the bundle adjustment algorithm (least-squares 339 network optimisation; Granshaw 1980) that improved their values during the camera alignment step 340 by incorporating GCPs and removing obvious outliers and incorrect matches from the sparse point 341 cloud. Moreover, the optimization process was done through appropriate weighting of tie and control 342 point image observations in bundle adjustment to enhance a real error characterisation (James et al., 343 2017a). (v) 3D high-density point clouds and orthomosaics: involved the implementation of MVS 344 image matching algorithms that increased the point density by several orders of magnitude (Woodget 345 et al., 2015), operating at the individual pixel scale to build dense clouds (Fig. 5b; Piermattei et al., 346 2015) and orthomosaics. Then mesh (Fig. 5c), tiled models (Fig. 5d) and orthomosaics were 347 generated and exported from Photoscan, being the resolution of these in agreement with the point 348 cloud density and the resolution of the photos. 

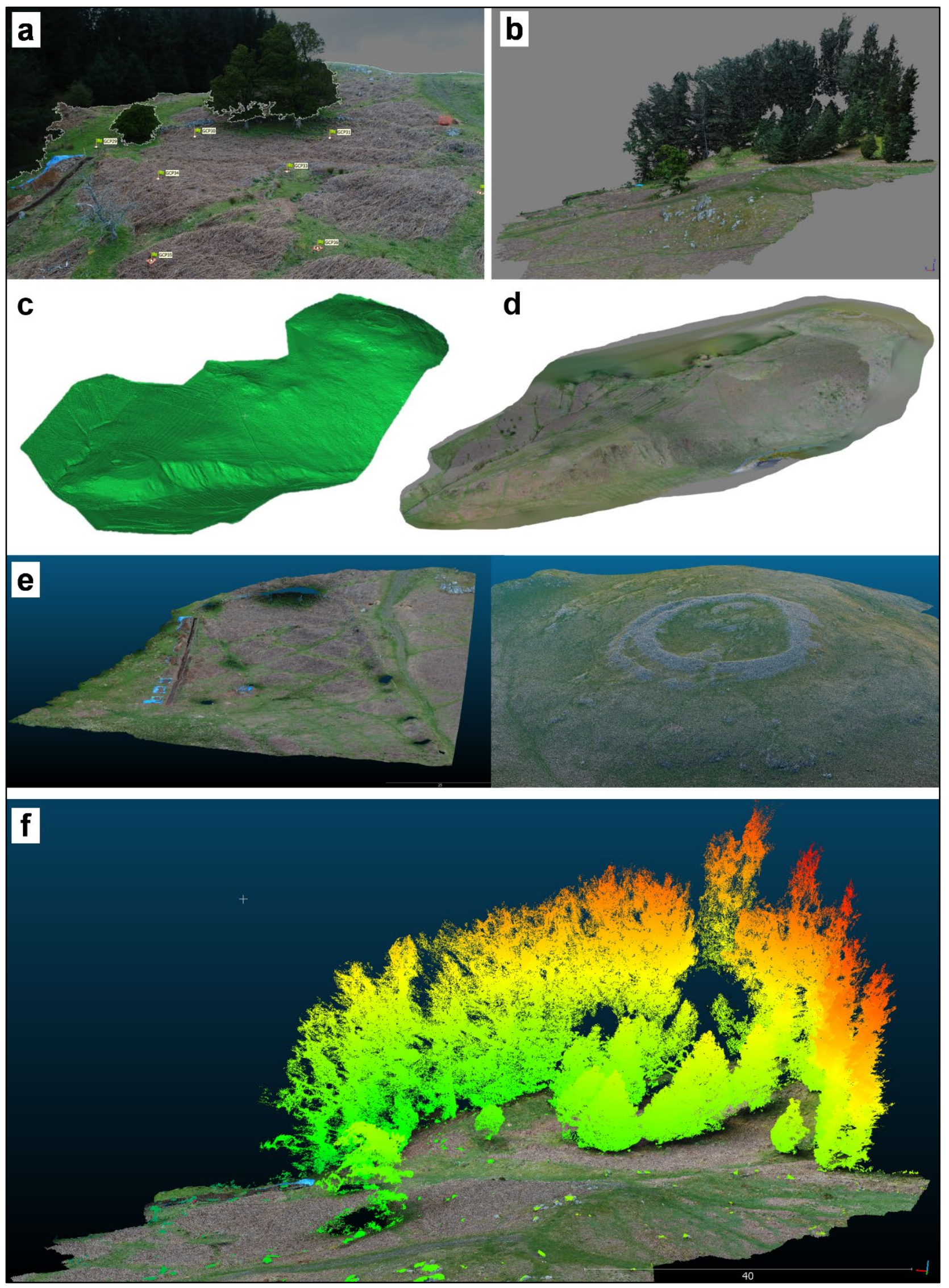

350 Figure 5: Examples of SfM processing steps and outputs. a) Photo of Ingram terrace area where the vegetated parts were masked and 351 GCPs were manually located in Agisoft Photoscan. b) Point cloud of vegetated area (Fig. 4c).c) Examples of the point cloud in Ingram 
area (terrace complex on the left and Brough Law hillfort at top right. d) The mesh at $0.25 \mathrm{~m}$ resolution viewing the site from the northeast looking up towards Plantation Camp terraces and Brough Law from the across the valley floor. e) Tiled model of the whole Ingram SfM survey. f) Example of CSF filter application to extract the ground points in very vegetated zone (Fig. 4c).

\subsubsection{SfM Post-processing}

The dense SfM point cloud had to be post-processed to minimize potential sources of error and noise in the topographic data because SfM technology presented frequent problems linked to photogrammetric workflow that could lead to numerous outliers and corrupt subsequent analysis (Smith et al., 2015; Carrivick et al., 2016) if the SfM process was not correctly applied. The first dense cloud editing was performed by means of the CloudCompare software (Omnia Version 2.10.2; http://www.danielgm.net) through a manual filtering, the Cloth Simulation Filter (CSF; Zhang et al., 2016) and the "SOR filter tool". The manual filter was used to delate unwanted objects in the point 363 cloud (e.g., isolated trees and shrub; Fig. 5e) while, the CSF filter (Fig. 5f) extracted the ground points in very vegetated and complex areas (Fig. 4c). Then the SOR filter was used to remove outliers through the computation of the average distance of each point to its neighbours (it rejects the points that are farther than the average distance plus a defined number of times the standard deviation). After the checking of possible alignment problems (displacements or differences in altitude between adjacent SfM surveys link to GNSS survey errors; Cucchiaro et al., 2019), the point cloud of different

SfM surveys (Fig. 3) were merged together in CloudCompare software generating a huge point cloud $\left(1,091,540,500\right.$ points with a mean density of 2700 points $\left./ \mathrm{m}^{2}\right)$ for the whole Ingram area.

\subsubsection{DTM generation}

The point cloud was decimated in order to reduce the processing constraints and the extremely high

373 density of the 3D cloud. The geostatistical Topography Point Cloud Analysis Toolkit (ToPCAT) 374 implemented in the Geomorphic Change Detection software for ArcGIS, (Wheaton et al., 2010; 375 available in http://gcd6help.joewheaton.org/) was used to decimate the point cloud. This tool (used 376 in several studies: e.g., Javernick et al. 2014; Marteau et al., 2017; Vericat et al., 2014) allows an 
intelligent decimation by decomposing the point cloud into a set of non-overlapping grid-cells and calculate statistics for the observations in each grid (e.g., minimum, mean, maximum elevation). Following the work by Brasington et al. (2012), the minimum elevation within each grid cell was considered the ground elevation and a grid cell of 0.10 meters was selected to regularize the data set. The point cloud obtained by ToPCAT $\left(37,180,100\right.$ points with a mean density of 100 points $\left./ \mathrm{m}^{2}\right)$ was used to calculate a Triangular Irregular Network (TIN) that was converted to rasters obtaining two DTMs.

\subsection{Result and Discussion}

The SfM workflow allowed the generation of a DTM at $0.25 \mathrm{~m}$ (Fig. 6a) for the whole Ingram area, while a higher resolution DTM $(0.10 \mathrm{~m}$; Fig. 6b) was carried out for the terrace complex so as to achieve a very detailed reconstruction of the topographic features of archaeological and geomorphological interest applicable to the TerrACE project. Compared to the DTM at $2 \mathrm{~m}$ resolution (Fig. 2b), the DTM at $0.25 \mathrm{~m}$ of Ingram Valley provided a significantly enhanced level of detail including much greater clarity of the prehistoric terrace system, the Plantation Camp enclosures, Brough Law hillfort and the medieval ridge and furrow and the overlying post-medieval stone-walled boundaries (Fig. 6a). Prior to this high resolution SfM survey the prehistoric terraces were virtually invisible on existing remote sensing data and hence why they were initially recognised from groundlevel survey and not from aerial photographs. Moreover, the higher resolution DTM $(0.10 \mathrm{~m})$ shows the terraces (Fig. 6b), Brough Law hillfort, Plantation Camp, and the ridge and furrow feature very clearly despite the severe problem of bracken infestation that severely obscures these and many more archaeological sites across the Cheviot Hills and Northumberland National Park. It also provided an accurate and high level of detail of the archaeological features and soil and sediment stratigraphy along the excavation trench (Fig. 6b). This high-resolution modelling has helped significantly in creating an accurate record of what is an awkward archaeological trench to record due to the range of elevation along its length and the complexity and subtle colour changes in the sediment stratigraphy 
observable in section. Furthermore, the output of the SfM workflow as point clouds allowed for the 403 extraction of profiles, sections, scaled plans ( $\underline{\text { Fig. } 7 \mathrm{a}}$ ) and orthomosaics (Fig. $7 \mathrm{~b})$ of the terrace 404 complex and the excavation trench (Fig. 7c). These tools, adding a clear visual dimension to the 405 drawn section, can make the archaeological work and measurements easier, faster, more accurate 406 whilst also allowing for more accurate and repeat interpretation. Indeed, these data can be useful to 407 extract metric of archaeological and geomorphological features that are to be included in the Ingram 408 archaeological report (Archaeological Research Services, n.d.). This HRT study has provided a level 409 of detail that had not been hitherto been achievable on this nationally important site and has overcome 410 many of the problems encountered when attempting to survey complex archaeological palimpsests 411 obscured by dense vegetation and situated on steep, non-uniform slopes. An additional terrace was 412 identified that had not been recognised before due to the HRT study bringing out a level of detail that 413 had not been previously observable. This has stretched the surviving extent of the terrace complex as 414 well as showing a direct relationship with the ridge and furrow cultivation remains which can be seen 415 to directly overly it. The trackway leading to Plantation Camp had been questioned by some 416 archaeologists, but now the clarity of the HRT study shows it very clearly and leading directly to 417 Plantation Camp and the top of the terrace complex (Fig. 7c). The methodology described in this 418 study has shown it to be a rapid, cost-effective and highly accurate technique for surveying 419 archaeological sites at both a landscape and localised scale and adding new and more accurate information in nationally important UK landscapes and beyond. 


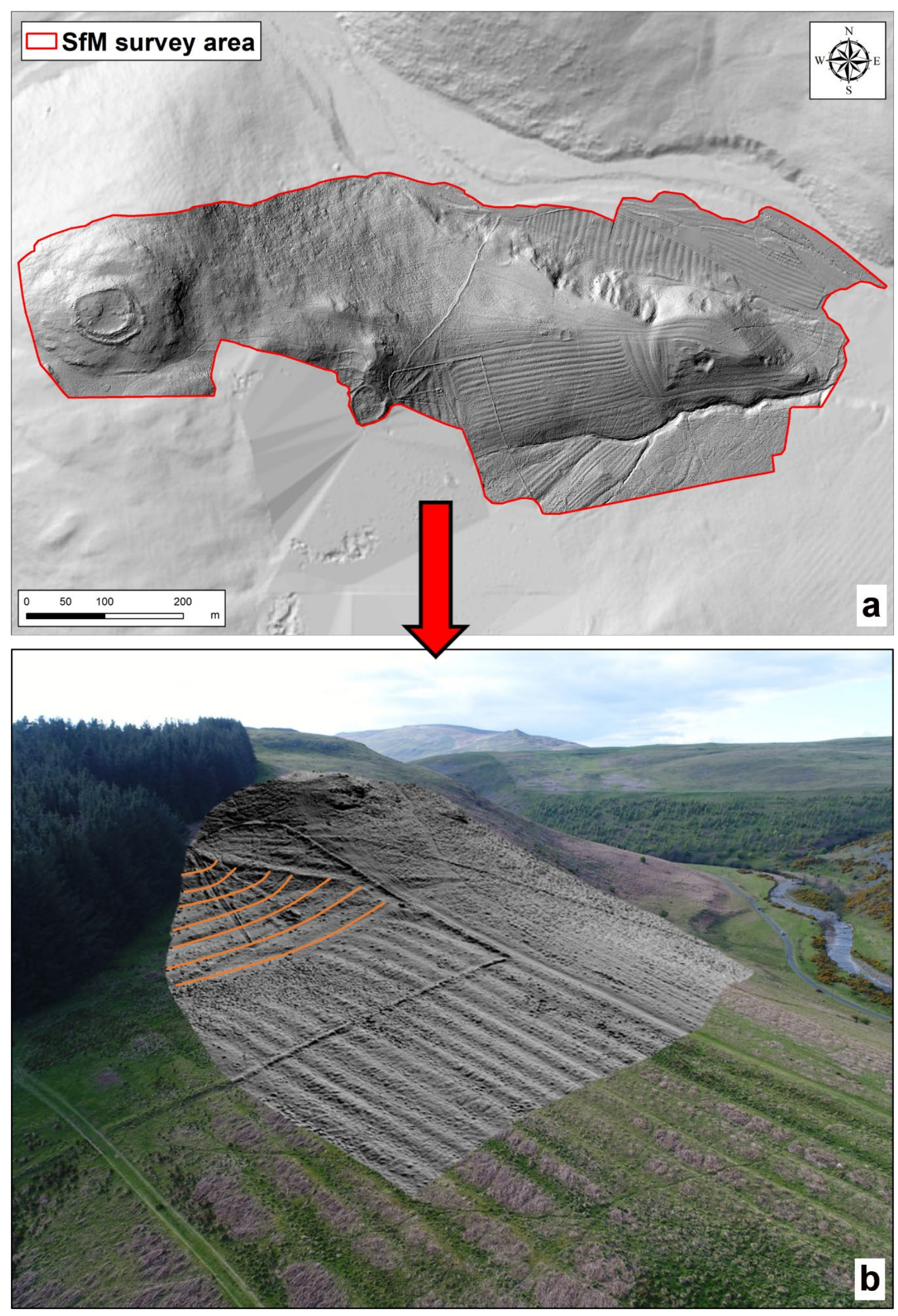

Figure 6: a) Shaded relief map of the SfM DTM at $25 \mathrm{~cm}$ on the DTM at $2 \mathrm{~m}$ resolution (Fig. 2b) for the Ingram Valley. The Brough

423 Law hillfort is to the left, the prehistoric agricultural terraces are central and to the immediate right of the Plantation Camp enclosures, 

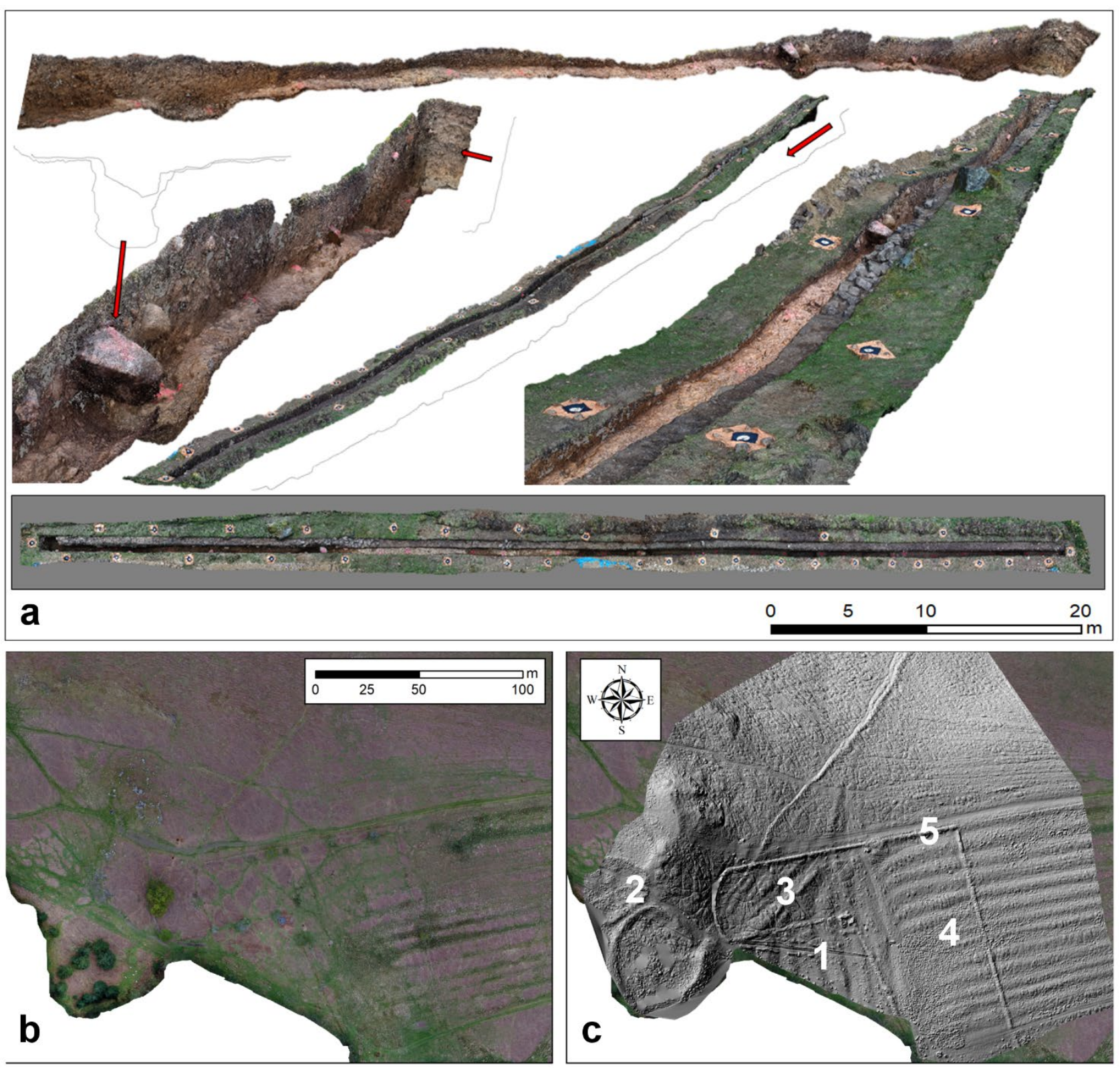

Figure 7: Useful SfM outputs for archaeological work. a) Point clouds, scaled plans, profiles and sections of the geoarchaeology

430 excavation trench. b) Detailed orthomosaic $(5 \mathrm{~cm})$ of the study area made through SfM technique. c) DTM at $0.1 \mathrm{~m}$ resolution looking 431 down vertically over the prehistoric agricultural terraces (n. 1), the Plantation Camp enclosures to the left (n. 2), the trackway (n. 3),

432 the medieval ridge and furrow to the right (n. 4) and post-medieval boundaries (n.5). 
The assessment of the GNSS and SfM surveys errors for the Ingram study area (Table 2) show that

434 the quality of SfM surveys was adequate for investigating topographic features of the terrace area and recording and analyzing the excavation trench structure.

Table 2: Characteristics of the GPS and SfM surveys for the Ingram study area and in particular for the trench zone. * 1/3 of the GCPS were used as $C P .{ }^{* *}$ Measures provided by Photoscan software. GCPs image precision reflects the precision in image space that GCP observations were made to, while tie points precision is the equivalent measure for the tie points.

\begin{tabular}{|c|c|c|c|c|c|c|}
\hline SfM survey & $\begin{array}{c}\text { Number of images } \\
\text { processed }\end{array}$ & $\begin{array}{c}\text { Number of GCPs } \\
\text { (as control, [as } \\
\text { check])* }\end{array}$ & $\begin{array}{c}\text { positional accuracy of } \\
\text { GCPs } \\
\text { (Easting-Northing }- \\
\text { Height; } \mathrm{m} \text { ) }\end{array}$ & $\begin{array}{c}\text { GCPs image } \\
\text { precision } \\
\text { (pixel }-\mathrm{m})^{* *}\end{array}$ & $\begin{array}{c}\text { Tie point } \\
\text { image } \\
\text { precision } \\
\text { (pixel - m)** }\end{array}$ & $\begin{array}{c}\text { CPs image } \\
\text { precision } \\
\text { (m)** }\end{array}$ \\
\hline All Ingram area & 3782 & $137[40]$ & $0.03-0.04$ & $1.014-0.075$ & $0.903-0.172$ & 0.078 \\
\hline Trench area & 570 & $80[27]$ & $0.03-0.04$ & $2.130-0.046$ & $0.873-0.152$ & 0.048 \\
\hline
\end{tabular}

The SfM survey results highlighted the benefits of the acquisition of data from two different observation directions and platforms (UAV and ground-based). This helped to $(i)$ avoid gaps in data; (ii) increase the individual point precision, point clouds density (Cucchiaro et al., 2018a; Stöcker et al., 2015), the robustness of topographic mapping and the high-resolution detail; and (iii) reduce error in estimated camera parameters, thus minimising systematic DTM deformation errors or large-area distortions (James et al., 2017a). Indeed, the ground-based photos provided a more accurate representation of complex surfaces for detail-scale 3D reconstruction, especially when steep or subvertical surfaces, such as the vertical walls of terraces, are surveyed (Cucchiaro et al., 2018a). This integrated approach preserved fine-grained topographic detail, permited accurate survey of highly vegetated area (Fonstad et al., 2013), while also allowing for the capture of large spatial data sets. The remarkable results of the SfM surveys at Ingram were also achieved through the careful distribution of GCPs across the study area. This influenced the final quality of the process of 452 georeferencing, mitigated systematic errors (Vericat et al., 2009; James et al., 2017b; James and 453 Robson 2012; Koci et al., 2017) and helped the merging between the different SfM surveys that had common GCPs. Indeed, the GCPs network was fundamental in this SfM survey because it allowed us to register and merge together very detailed and high-resolution surveys that otherwise would not 
be possible to manage due to the huge number of images acquired for a large study area such as that

457 at Ingram. The alignment process was fundamental to increase the quality of the whole point cloud 458 (Cucchiaro et al., 2019).

459 The limited ability to process very heavy SfM data (in terms of Gigabytes) for wide study areas is 460 perhaps the potential weakness in this approach. However, a robust SfM workflow and technological 461 developments can certainly help to increase the performance of this technique. The present work 462 highlights how the precision in SfM surveys could only be guaranteed through a careful planning of 463 appropriate survey, accurate data post-processing, and an uncertainty assessment, identifying and 464 minimizing the potential sources of error in SfM topographic data.

\section{Final remarks}

The SfM photogrammetry technique has provides a number of advances for geoarchaeological 467 studies, but it can produce datasets containing large errors, if not correctly applied, especially in wide and complex topographic zones, and in terrains dominated by vegetation. As shown by the case study discussed in this chapter, SfM technique carried out low cost (and time) HRT for large areas, showing the different dimensions, orientations and distribution of cultivation-related and settlement

471 features. This technique allowed rapid, accurate survey of complex archaeological features at a 472 landscape scale that are otherwise almost unsurveyable due to dense vegetation cover - in this case 473 bracken infestation, thereby revealing new archaeological remains, as well as confirming physical 474 relationships, and thus chronostratigraphic relationships within and between component monuments. 475 Moreover, SfM can be effective in the estimation of metrics and geomorphological features of 476 cultivation terraces such as riser height and slopes from high-resolution DTMs. SfM produced 477 archaeological recording of excavation trenches by integrating ground-based and UAV survey which 478 can add a 3D element to traditional section mosaics and allows integrated archiving of surface and 479 sub-surface data. Indeed, this photogrammetric technique extracted 3D models, profiles, sections, 
480 scaled plans and orthomosaic of trench excavations, simplifying and speeding the archaeologist's field 481 and post-excavation work.

482

483 Acknowledgements

484 The research is funded by Advanced ERC Grant TerrACE: Terrace Archaeology and Culture in 485 Europe (ERC-2017-ADG: 787790, 2018-2023, https://www.terrace.no/). The authors acknowledge 486 help and support from the Northumberland National Park and landowners. A special thank all those 487 involved with the project, particularly all of the volunteers who put in a tremendous amount of effort 488 during the excavations. We would also like to thank Lee McFarlane, the Historic England Inspector 489 of Ancient Monuments, Chris Jones, Historic Environment Officer at Northumberland National Park, 490 who supported and advised on the archaeological works and Ross Wilson from Ingram Farm.

491

492

493

494

495

496

497

498

499 


\section{References:}

501 AgiSoft LLC, 2010. Agisoft Lens User-Manual. Version 1.2.0. http://www.agisoft.com/downloads/user-manuals.

502 [Accessed on 22 June 2019].

503 Aqdus, S.A., Drummond, J., Hanson, W.S., 2008. Discovering archaeological cropmarks: a hyperspectral approach. The 504 International Archives of the Photogrammetry, Remote Sensing and Spatial Information Sciences 37, 361-366.

Archaeological Research Services, n.d. in preparation. Survey and Excavation at Plantation Camp Agricultural Terraces,

Ingram, Northumberland. Archaeological Research Services Report No.

Barber, M., 2011. A History of Aerial Photography and Archaeology: Mata Hari’s glass eye and other stories. Historic

Beach, T., Beach, S.L., Krause, S., Guderjan, T., Valdez Jr., F., Fernandez-Diaz, J.C, Eshleman, S., Doyle, C. 2019.

512 Ancient Maya wetland fields revealed under tropical forest canopy from laser scanning and multiproxy evidence. PNAS. $513116,21469-21477$.

514 Bemis, S.P., Micklethwaite, S., Turner, D., James, M.R., Akciz, S., Thiele, S.T., Bangash, H.A., 2014. Ground-based and 515 UAV-Based photogrammetry: A multi-scale, high-resolution mapping tool for structural geology and paleoseismology. 516 J Struct Geol 69:163-178.

517 Blasone, G., Cavalli, M., Marchi, L., Cazorzi, F., 2014. Monitoring sediment source areas in a debris-flow catchment 518 using terrestrial laser scanning. Catena 123:23-36.

519 Bojakowski, P., Bojakowski, K. C., \& Naughton, P., 2015. A comparison between structure from motion and direct survey 520 methodologies on the Warwick. Journal of Maritime Archaeology, 10(2), 159-180.

521 Brasington, J., Vericat, D., Rychkov, I., 2012. Modeling riverbed morphology, roughness, and surface sedimentology using high-resolution terrestrial laser scanning. Water Resour Res 48:1-18.

523 Brown, A. G., Schneider, H., Rice, R.J., Milton, E.J., 1990. Remote sensing soil erosion: airborne thematic mapper data 524 on soil variation in Mediterranean arable land in Southern Spain. In Procs. of the NERC Symposium on Airborne Remote 525 Sensing 1990, British Geological Survey, Keyworth, Nottingham, 7-18. 
Brown, A. G. 2008. Geoarchaeology, the four dimensional (4D) fluvial matrix and climatic causality. Geomorphology $101,278-297$.

Brutto, M.L., Sciortinoa, R., Garraffaa, A., 2017. RPAS and TLS techniques for archaeological survey: the case study of the archaeological site of Eraclea Minoa (Italy). The International Archives of the Photogrammetry, Remote Sensing and Spatial Information Sciences 52, 433-438.

Carey, C. J., Brown, A.G., Challis, K. C., Howard, A., Cooper, L., 2006. Predictive modelling of multi-period Geoarchaeological Resources at a River Confluence. Journal of Archaeological Prospection 13, 241-250.

Carey, C., Howard, A. J., Jackson, R., Brown, A.G., 2017. Utilizing multi-period geoarchaeological predictive models as a framework for archaeological investigation in river valleys: an integrated case study from the Lugg, Valley, Herefordshire, UK. Journal of Archaeological Science Reports 11, 658-673.

Carrivick, J.L., Smith, M.W., Quincey, D.J., 2016. Structure from Motion in the Geosciences. New Analytical Methods in Earth and Environmental Science. WILEY-BLACKWELL.

Carrivick, J.L., Smith, M.W., 2018. Fluvial and aquatic applications of Structure from Motion photogrammetry and unmanned aerial vehicle/drone technology. Wiley Interdisciplinary Reviews: Water, 6 (1). e1328. ISSN 2049-1948.

540 Cavalli, R., Colosi, F., Palombo, A., Pignatti, S., Poscolieri, M., 2007. Remote hyperspectral imagery as a support to archaeological prospection. Journal of Cultural Heritage 8, 272-283

Chen, J., Li, K., Chang, K.J., Sofia, G., Tarolli, P., 2015. Open-pit mining geomorphic feature characterisation. Int. J. Appl. Earth Obs. Geoinf. 42, 76-86.

544 Clapuyt, F., Vanacker, V., Van Oost, K., 2016. Reproducibility of UAV-based earth topography reconstructions based on Structure-from-Motion algorithms. Geomorphology 260: 4-15.

546 Clapuyt, F., Vanacker, V., Schlunegger, F., Van Oost, K., 2017. Unravelling earth flow dynamics with 3-D time series 547 derived from UAV-SfM models. Earth Surf Dyn 5:791-806.

548 Cucchiaro, S., Cavalli, M., Vericat, D., Crema, S., Llena, M., Beinat, A., Marchi, L. and Cazorzi, F., 2018a. Monitoring topographic changes through 4D-structure-from-motion photogrammetry: application to a debris-flow channel. Environ 
551 Cucchiaro, S., Cavalli, M., Vericat, D., Crema, S., Llena, M., Beinat, A., Marchi, L., Cazorzi, F., 2019. Geomorphic 552 effectiveness of check dams in a debris-flow catchment using multi-temporal topographic surveys. Catena 174, 73-83.

553 Cucchiaro, S., Maset, E., Fusiello, A., Cazorzi, F., 2018b. 4D-SfM photogrammetry for monitoring sediment dynamics 554 in a debris-flow catchment: software testing and results comparison. Int. Arch. Photogramm. Remote Sens. Spat. Inf. Sci. 555 XLII-2, 281-288.

Dietrich, J.T., 2017. Bathymetric Structure-from-Motion: extracting shallow stream bathymetry from multi-view stereo photogrammetry. Earth Surf Process Landf 42:355-364.

Doyon, W., Adams, M.D., Simmons, B., 2019. Photogrammetry is the new archaeological photography: 3D modelling at Abydos March 14, 2019. Abydos Archaeology.

Eker, R., Aydın, A., Hübl, J., 2018. Unmanned aerial vehicle (UAV)-based monitoring of a landslide: Gallenzerkogel landslide (Ybbs-Lower Austria) case study. Environ. Monit. Assess. 190:28

Eltner, A., Kaiser, A., Castillo, C., Rock, G., Neugirg, F., Abellán, A., 2016. Image-based surface reconstruction in geomorphometry-merits, limits and developments. Earth Surf Dyn 4:359-389.

Evans, D.H., et al. 2013. Uncovering archaeological landscapes at Angkor using lidar. Proc. Natl. Acad. Sci. U.S.A. 110, $12595-12600$.

Fonstad, M.A., Dietrich, J.T., Courville, B.C., Jensen, J.L., Carbonneau, P.E., 2013. Topographic structure frommotion: a new development in photogrammetric measurement. Earth Surf Process Landf 38:421-430.

569 Frodsham, P., Waddington, C., 2004. The Breamish Valley Archaeology Project 1994-2002. In Frodsham, P. (ed.) 570 Archaeology in Northumberland National Park: 171-189. Council for British Archaeology, Research Report 136.

571 Fussell, A. 1982. Terrestrial Photogrammetry in Archaeology. World Archaeology 14, 157-172.

572 Georges-Leroy, M., Dambrine, E., Dupouey, J-L., Etienne, D., 2013. Lidar helps to decipher land-use history in Lorrain, 573 France. In Understanding Landscapes, from land Discovery to their Spatial Organisation, Conference: Proceedings of the 574 XVI World Congress of the International Union of Prehistoric and Protohistoric Sciences at Florianopolis, Brazil 115- 
Glendell, M., McShane, G., Farrow, L., James, M.R., Quinton, J., Anderson, K., Evans, M., Benaud, P., Rawlins, B., 577 Morgan, D., Jones, L., Kirkham, M., DeBell, L., Quine, T.A., Lark, M., Rickson, J., Brazier, R.E., 2017. Testing the 578 utility of structure-from-motion photogrammetry reconstructions using small unmanned aerial vehicles and ground 579 photography to estimate the extent of upland soil erosion. Earth Surf Process Landf 42:1860-1871.

580 González-Aguilera, D., Muñoz-Nieto, A., Gómez-Lahoz, J., Herrero-Pascual, J., Gutierrez-Alonso, G., 2009. 3D Digital 581 Surveying and Modelling of Cave Geometry: Application to Paleolithic Rock Art. Sensors 9, 1108-1127

582 Granshaw, S.I., 1980. Bundle adjustment methods in engineering photogrammetry. Photogramm. Rec. 10 (56):181-207.

583 Guyot, A., Lennon, M., Thomas, N., Gueguen, S., Petit, T., Lorho, T., Cassen, S., Hubert-Moy, L. 2019. Airborne 584 Hyperspectral Imaging for Submerged Archaeological Mapping in Shallow Water Environments. Remote Sens. 2019, $585 \quad 11,2237-2257$.

586 Hämmerle M., Höfle B., 2018. Introduction to LiDAR in Geoarchaeology from a Technological Perspective. In: Siart C., 587 Forbriger M., Bubenzer O. (eds) Digital Geoarchaeology. Natural Science in Archaeology. Springer, Cham.

588 Hoyle, J., 2008: The Forest of Dean, Gloucestershire Lidar survey of selected areas of woodland and the Aggregates 589 Resource Area. Archaeology Service, Gloucestershire County Council.

590 Howland, M.D., Kuester, F., Levy, T.E., 2014. Structure from motion: twenty-first century field recording with 3D 591 technology. Near Eastern Archaeol. 77 (3), 187-191.

592 Iglhaut, J., Cabo, C., Puliti, S., Piermattei, L., O’Connor, J., Rosette, J., 2019. Structure from Motion Photogrammetry in 593 Forestry: a Review. Curr. For. Reports 5, 155-168.

594 Immerzeel, W.W., Kraaijenbrink, P.D.A., Shea, J.M., Shrestha, A.B., Pellicciotti, F., Bierkens, M.F.P., de Jong, S.M., 595 2014. High-resolution monitoring of Himalayan glacier dynamics using unmanned aerial vehicles. Remote Sens Environ $596 \quad 150: 93-103$.

597 James, M.R., Robson, S., 2012. Straightforward reconstruction of 3D surfaces and topography with a camera: accuracy 598 and geoscience application. J Geophys Res 117, F03017.

599 James, M.R., Robson, S., 2014. Mitigating systematic error in topographic models derived from UAV and ground-based 600 image networks. Earth Surf Process Landf 39:1413-1420. 

processed with structurefrom-motion: ground control quality, quantity and bundle adjustment. Geomorphology 280:5166.

James, M.R., Robson, S., Smith, M.W., 2017b. 3-D uncertainty-based topographic change detection with structure-frommotion photogrammetry: precision maps for ground control and directly georeferenced surveys. Earth Surf Process Landf 42:1769-1788.

Javernick, L., Brasington, J., Caruso, B., 2014. Modeling the topography of shallow braided rivers using Structure-fromMotion photogrammetry. Geomorphology 213:166-182.

Johnson, N., Bonney, D., Rose, P., 2008. Bodmin Moor An archaeological survey Volume 1: The human landscape to c 1800. English Heritage, London.

611 Kinnaird, T., Bolòs, J., Turner, A., Turner, S., 2017. Optically-stimulated luminescence profiling and dating of historic agricultural terraces in Catalonia (Spain). Journal of Archaeological Science 78: 66-77.

613 Koci, J., Jarihani, B., Leon, J.X., Sidle, R., Wilkinson, S., Bartley, R., 2017. Assessment of UAV and Ground-Based 614 Structure from Motion with Multi-View Stereo Photogrammetry in a Gullied Savanna Catchment. ISPRS Int J GeoInformation 6: 328.

Kouchoukos, N., 2001. Satellite Images and Near Eastern Landscapes. Near Eastern Archaeology 64, (1/2), 80-91.

Landeschi, G., Nilsson, B., Dell'Unto, N., 2016. Assessing the damage of an archaeological site: New contributions from the combination of image-based 3D modelling techniques and GIS. J. Archaeol. Sci. Reports 10, 431-440.

Lasaponara, R., Masini, N., 2007. Detection of archaeological crop marks by using satellite QuickBird multispectral imagery. Journal of Archaeological Science 34, 214-221.

Lasaponara, R., Masini, N., 2011. Satellite remote sensing in archaeology: past, present and future perspectives. Journal of Archaeological Science 38, 1995-2002.

Lim, M., Rosser, N. J., Allison, R. J. and Petley, D. N., 2010. Erosional processes in the hard rock coastal cliffs at Staithes, North Yorkshire. Geomorphology 114: 12-21.

Linderholm, J., Geladi, P., Goretta, N., Bendoula, R., Gobrecht, A. 2019. Near infrared and hyperspectral studies of archaeological stratigraphy and statistical considerations. Geoarchaeology 34:311-321. 
Lobb, M., Brown, A.G., 2016. Terrestrial Laser Scanning and Coastal Erosion at Low Hauxley. In C. Waddington and C.

628 Bonsall (Eds.) Archaeology and environment on the North Sea littoral: A case study from Low Hauxley. Oxbow Books, 629 Oxford, 291-301.

630 Lobb, M., Brown, A.G., Leyland, J., Bernard, V., Daire, M.Y., Langouët, L., In Press. An estuarine tide-scape of 631 production: terrestrial laser scanning (TLS) of fixed fishing structures and a tidal mill in the Léguer Estuary, Brittany. 632 Antiquity.

633 López, J.A.B., Jiménez, G.A., Romero, M.S., García, E.A., Martín, S.F., Medina, A.L., Guerrero, J.A.E., 2016. 3D modelling in archaeology: The application of Structure from Motion methods to the study of the megalithic necropolis of Panoria (Granada, Spain). J. Archaeol. Sci. Reports 10, 495-506. Investigation for an Archaeological Evaluation. Archaeological Research Services Ltd., 19p.

Malambo, L., Popescu, S.C., Murray, S.C., Putman, E., Pugh, N.A., Horne, D.W., Richardson, G., Sheridan, R., Rooney, 639 W.L., Avant, R., Vidrine, M., McCutchen, B., Baltensperger, D., Bishop, M., 2018. Multitemporal field-based plant height estimation using 3D point clouds generated from small unmanned aerial systems high-resolution imagery. Int. J. Appl. Earth Obs. Geoinf. 64, 31-42.

Mallalieu, J., Carrivick, J.L., Quincey, D.J., Smith, M.W., James, W.H.M., 2017. An integrated Structure-from-Motion and time-lapse technique for quantifying ice-margin dynamics. J Glaciol 63:937-949.

644 Marteau, B., Vericat, D., Gibbins, C., Batalla, R.J., Green, D.R., 2017. Application of Structure-from-Motion photogrammetry to river restoration. Earth Surf Process Landf 42:503-515.

Mertes, J., Thomsen, T., Gulley, J., 2014. Evaluation of structure from motion software to create $3 \mathrm{~d}$ models of late nineteenth century great lakes shipwrecks using archived diver-acquired video surveys. Journal of Maritime Archaeology, 9(2), 173-189.

MHEF (Minerals and Historic Environment Forum), 2008. Mineral Extraction and Archaeology: A Practice Guide. London, English Heritage on behalf of the Minerals and Historic Environment Forum.

651 New Forest 2016. Laser mapping uncovers hidden secrets in the New Forest. 652 http://www.hlsnewforest.org.uk/2016/01/25/laser-mapping-uncovers-hidden-secrets-of-the-new-forest/. [Accessed on 653 October 2019]. 
O’Connor, J., Smith, M.J., James, M.R., 2017. Cameras and settings for aerial surveys in the geosciences: Optimising image data. Progress in Physical Geography: Earth and Environment 41: 325-344.

Parcak, S., 2007. Satellite Remote Sensing Methods for Monitoring Archaeological Tells in the Middle East. Journal of Field Archaeology, 32 (1) 65-81.

Passmore, D.G., Waddington, C., 2009. Managing Archaeological Landscapes in Northumberland. Till-Tweed Studies Volume 1. Oxford, Oxbow Books and English Heritage.

Passmore, D.G., Waddington, C., 2012. Archaeology and Environment in Northumberland. Till-Tweed Studies Volume 2. Oxford, Oxbow Books and English Heritage. gradual decline rather than a catastrophic 15th-century collapse. PNAS, 116 (11) 4871-4876.

Pierdicca, R., Frontoni, E., Malinverni, E.S., Colosi, F., Orazi, R., 2016. Virtual reconstruction of archaeological heritage using a combination of photogrammetric techniques: Huaca Arco Iris, Chan Chan, Peru. Digit. Appl. Archaeol. Cult. Herit. 3, 80-90.

Piermattei, L., Carturan, L., Guarnieri, A., 2015. Use of terrestrial photogrammetry based on structure-from-motion for mass balance estimation of a small glacier in the Italian Alps. Earth Surf Process Landf 40:1791-1802.

Piermattei, L., Karel, W., Vettore, A., Pfeifer, N., 2016. Panorama image sets for terrestrial photogrammetric surveys. ISPRS Annals of the Photogrammetry, Remote Sensing and Spatial Information Sciences, Volume III-5, 159-166. resolution topographic data. Water 11,814 .

Pijl, A., Bailly, J-B., Feurer, D., El Maaoui, M.A., Boussema, M. R., Tarolli, P., 2020. TERRA: Terrain Extraction from elevation Rasters through Repetitive Anisotropic filtering. International Journal of Applied Earth Observation and Geoinformation, 84, 101977. 
Romano, D.G., Tolba., O., 1996. "Remote Sensing and GIS in the Study of Roman Centuriation in the Corinthia, Greece."

680 In Interfacing the Past: Computer Applications and Quantitative Methods in Archaeology CAA95. 2 vols., edited by H. 681 Kamermans and K. Fennema, 457-63. Analecta Praehistorica Leidensia 28. Leiden: University of Leiden.

682 Rosser, N.J., Petley, D.N., Lim, M., Dunning, S.A., Allison, R.J., 2005. Terrestrial laser scanning for monitoring the 683 process of hard rock coastal cliff erosion. Quarterly Journal of Engineering Geology and Hydrogeology; 38 (4): 363-375.

684 Skrede, M.A., 2005. 'Utmark’ the Outfields and Industry and Idealogy in the Iron Age. In Holm et al. (Eds.) University 685 of Bergen Archaeological Series International 1,31-41.

686 Smith, M., Vericat, D., 2015. From experimental plots to experimental landscapes: topography, erosion and deposition in 687 sub-humid badlands from Structure-from-Motion photogrammetry. Earth Surf Process Landf 40:1656-1671.

688 Smith, M.W., Carrivick, J.L., Quincey, D.J., 2015. Structure from motion photogrammetry in physical geography. Prog 689 Phys Geogr 40:247-275.

690 Sofia, G., Marinello, F., Tarolli, P., 2014. A new landscape metric for the identification of terraced sites: The Slope Local 691 Length of Auto-Correlation (SLLAC). ISPRS J. Photogramm. Remote Sens. 96, 123-133.

692 South Downs National Park 2019. Secrets of High Woods. https://www.southdowns.gov.uk/discover/heritage/secrets-of693 the-high-woods/. [Accessed on October 2019].

694 Stöcker, C., Eltner, A., Karrasch, P., 2015. Measuring gullies by synergetic application of UAV and close-range 695 photogrammetry - A case study from Andalusia, Spain. Catena 132:1-11.

696 Stumpf, A., Malet, J.P., Allemand, P., Pierrot-Deseilligny, M., Skupinski, G., 2015. Ground-based multi-view 697 photogrammetry for the monitoring of landslide deformation and erosion. Geomorphology 231:130-145.

698 Tarolli, P., 2014. High-resolution topography for understanding Earth surface processes: Opportunities and challenges. 699 Geomorphology 216:295-312.

700 Tarolli, P., Preti, F., Romano, N., 2014. Terraced landscapes: From an old best practice to a potential hazard for soil 701 degradation due to land abandonment. Anthropocene 6, 10-25.

702 Tarolli, P., Cao, W., Sofia, G., Evans, D., Ellis, E.C., 2019. From features to fingerprints: A general diagnostic framework 703 for anthropogenic geomorphology. Prog. Phys. Geogr. Earth Environ. 43, 95-128. 
Turner, D., Lucieer, A., de Jong, S.M., 2015. Time series analysis of landslide dynamics using an Unmanned Aerial

Van Oost et al., 2000. Evaluating the effects of changes in landscape structure on soil erosion by water and tillage. Landsc. Ecol. 15, 579-591.

Verhoeven, G.J., 2012. Near-Infrared Aerial Crop Mark Archaeology: From its Historical Use to Current Digital 711 Implementations. Journal of Archaeological Method Theory 19:132-160.

712 Verhoeven, G.J., Smet, P.F. Poelman, D., Vermeulen, F., 2009. Spectral Characterization of a Digital Still Camera's NIR 713 Modification to Enhance Archaeological Observation. IEEE Transactions on Geoscience and Remote Sensing 47, (10), $714 \quad 3456-3468$.

715 Vericat, D., Brasington, J., Wheaton, J., Cowie, M., 2009. Accuracy assessment of aerial photographs acquired using lighter-than-air blimps: low-cost tools for mapping river corridors. River Res Appl 28:985-1000.

717 Vericat, D., Smith, M., Brasington, J., 2014. Patterns of topographic change in sub-humid badlands determined by high718 resolution multi-temporal topographic surveys. Catena 120:164-176.

719 Victoriano, A., Brasington, J., Guinau, M., Furdada, G., Cabré, M., Moysset, M., 2018. Geomorphic impact and assessment of flexible barriers using multi-temporal LiDAR data: the Portainé mountain catchment (Pyrenees). Eng. Geol. $721237,168-180$.

722 Walsh, K., Mocci, F., 2003. Fame and marginality: the archealogy of Montagne Sainte Victorie (Provence, France). Am. J. Arch. 107, 45-69.

Walsh, K., Brown, A.G., Gourley, B. Scaife, R., 2017. Archaeology, Hydrogeology and Geomythology in the Stymphalos Valley. Journal of Archaeological Science Reports. 15, 446-458

Westoby, M.J., Brasington, J., Glasser, N.F., 2012. 'Structure-from-Motion' photogrammetry: A low-cost, effective tool for geoscience applications. Geomorphology 179:300-314. topographic surveys: improved sediment budgets. Earth Surf Process Landf 35:136-156. 
730 Whitworth, M., Giles, D., Anderson, I., Clewitt, M., 2006. Terrestrial laser scanning for applied geoscience studies in the 731 urban environment. IAEG2006 Paper number 252: 1-9.

732 Williams, J.G., Rosser, N.J., Hardy, R.J., Brain, M.J., Afana, A.A., 2018. Optimising 4-D surface change detection: An 733 approach for capturing rockfall magnitude-frequency. Earth Surf. Dyn. 6, 101-119.

734 Woodget, A.S., Carbonneau, P.E., Visser, F., Maddock, I.P., 2015. Quantifying submerged fluvial topography using 735 hyperspatial resolution UAS imagery and structure from motion photogrammetry. Earth Surf Process Landf 40:47-64.

736 Zarco-Tejada, P.J., Diaz-Varela, R., Angileri, V., Loudjani, P., 2014. Tree height quantification using very high-resolution 737 imagery acquired from an unmanned aerial vehicle (UAV) and automatic 3D photo-reconstruction methods. Eur. J. 738 Agron. 55, 89-99.

739 Xiang J., Chen J., Sofia G., Tian Y., Tarolli P., Open-pit mine geomorphic changes analysis using multi-temporal UAV 740 survey, Environmental Earth Sciences 77, 2018, 220.

741 Zhang, W., Qi, J., Wan, P., Wang, H., Xie, D., Wang, X., Yan, G., 2016. An Easy-to-Use Airborne LiDAR Data Filtering 742 Method Based on Cloth Simulation. Remote Sensing. 8(6):501. 